\title{
ON THE UDMURT WATER SPIRIT AND THE FORMATION OF THE CONCEPT 'HOLY' AMONG PERMIAN PEOPLES
}

\section{Aado Lintrop}

\section{INTRODUCTION}

Having set out to study the Udmurt mythology I was amazed by how little attention has been given a supernatural creature that I consider extremely intriguing in modern folklore studies. This creature is vožo, a water-related being who is widely discussed in the studies into the Udmurt folk belief by the late 19th century and early 20 th century authors. ${ }^{1}$ Vladimir Vladykin's fundamental treatment of the Udmurt mythology discusses vožo in connection to popular calendar, mentioning that the winter solstice period ends with a ritual called jö vile sulton: ${ }^{2}$ the common belief associated with it was that "this day all the "filth or impurity" - vožoos ${ }^{3}$ - goes under water" (Vladykin 1994: 229). Tatyana Vladykina touches upon vožo in her monograph on genre issues in connection with genre names and mumming (Vladykina 1998: 11, 14, 53-55, 84). The only author who has written singularly on vožo is Irina Pletneva, who has briefly summarised everything written on the subject (Pletneva 1999). In his article on supernatural creatures connected to the Udmurt buildings Ranus Sadikov writes: "Several peoples have believed that at a certain period of time the saunas will be inhabited by spirits closely associated with water. The Komi-permyaks, for example, believed that kulpijannez, ${ }^{4}$ or water spirits, come to sauna to warm themselves" (Sadikov 2000: 116). For some reason he makes no reference to vožo, which was known mainly in the traditions of the Northern-Udmurts. In December 2002 Galina Glukhova (supervisor T. Vladykina) defended her doctor's thesis on the tradition of mumming, where the author also touches upon beliefs associated with vožo (Glukhova 2002: 7-10). 
Becoming further involved in the subject, it began to appear to me that vožo is something like a key figure in the evolution of religious thought among the Permian peoples. Under the word 'evolution' I do not mean a progress from a lower level, or a simpler form, to a higher level, or into a more complex form, but a process of continuous, though very common change of meanings that all human concepts are subject to. Now I have come to the concept of 'holy', which development in the Permian tradition would remain incomplete without the concept of vožo. The notion 'holy' that will be discussed below is not holy in its modern, Christian sense. Vožo enables us to take a look into the worldview of people centuries ago, when the divine and the infernal were not separated by an unsurpassable gap. And since we cannot discuss vožo separately from other waterrelated mythological creatures, I will first observe the Udmurt beliefs associated with water spirits.

\section{UDMURT WATER SPIRITS}

For me, water spirit is a conditional common name for several water-related supernatural creatures, which are difficult, if not impossible, to distinguish. In the following I will shortly present narrative motifs associated with three mythological characters in the Udmurt mythology. ${ }^{5}$ In order to fully comprehend their idiosyncrasies and scope, I will compare these characters against several Northern-European mythologies, by drawing parallels with motifs from the works of Stith Thompson and Antti Aarne.

\section{1. vumurt or vu kuźo (water + man; water + master)}

This mythological character is anthropomorphic and dwells in rivers (MI F212.Fairyland under water; G303.8.8. Devil lives in the water). Vumurt has a large family (MI F420.3.1.Water-spirits have family life under water). It is wealthy, heads a prosperous household and a large herd (MI F241.2.3. Faires' cattle under a lake; F420.4.8. Water-spirits have treasures under water), and sometimes appears either as a beautiful woman (MI F420.1.2.1. Water-maidens are of un unusual beauty) or is dirty, ugly and hairy (MI F451.2.0.1. Dwarfs are ugly). Vumurt usually appears as a naked human, most often as a woman (MI F420.1.6.7. Water-spirits are 
ude), who sits on the wheel of a water mill or on the river bank and combs her long hair (MI F420.5.3.1. Water-spirits sit on beach combing their long hair). Vumurt often visits marketplaces and fairs (MI F420.3.2.2. Water-women come to market and store), has the appearance of a regular farmer in the crowd (MI F420.1.6.1. Water spirits are dressed like people around them), but can be recognised by the coat, which left skirt/corner is always wet (MI F420.1.7.1. Corner of water-spirits' dress is always wet).

In narratives water spirits become visible to the hero by a special ointment or liquid that the hero spreads on his eyelids. In some variants a midwife smears her eyelids with the faeces of a water spirit's newborn child (MI F235.4.1. Fairies made visible through use of ointment; F235.4.4. Fairies made visible through use of magic water).

Some reports suggest that it was believed that vumurt had a single eye at the back of its head (ogre, the Devil), and that its fingers dropped off and could be found at river banks (oblong finger-shaped stones have been called 'vumurt's fingers' - Pervukhin 1888, 1: 73; Vereshtshagin 1996: 90).

Seeing a vumurt was sometimes considered an omen of an illness or calamity.

Vumurt may have married a human (MI F420.6.1.1. Water-man woos mortal girl). It may have drowned people (MI F420.5.2.1. Waterspirits lure mortal into water) and posed a threat to those who choose to swim at a wrong time, were not wearing crosses, etc. In a commonly knwon motif a water spirit summons a midwife to its wife in labour (MI F372.1. Fairies take human midwife to attend fairy woman; F420.5.3.2. Water-spirit calls human midwife, F451.5.5. Dwarfs have human woman as midwife). The water spirit generously rewards the midwife, but the money/gold turns into coals or leaves (MI G303.21.1. Devil's money becomes ashes).

Sometimes vumurt acts as a treasure bringer. By this attribute it is related to the treasure-bringing goblins (kratt, puuk, para), known in the Estonian and Finnish tradition. In folk tales it is often attributed the role of an ignorant Old Heathen (MI K171.1. Deceptive crop division: above the ground, below the ground: AT 1030 Shar- 


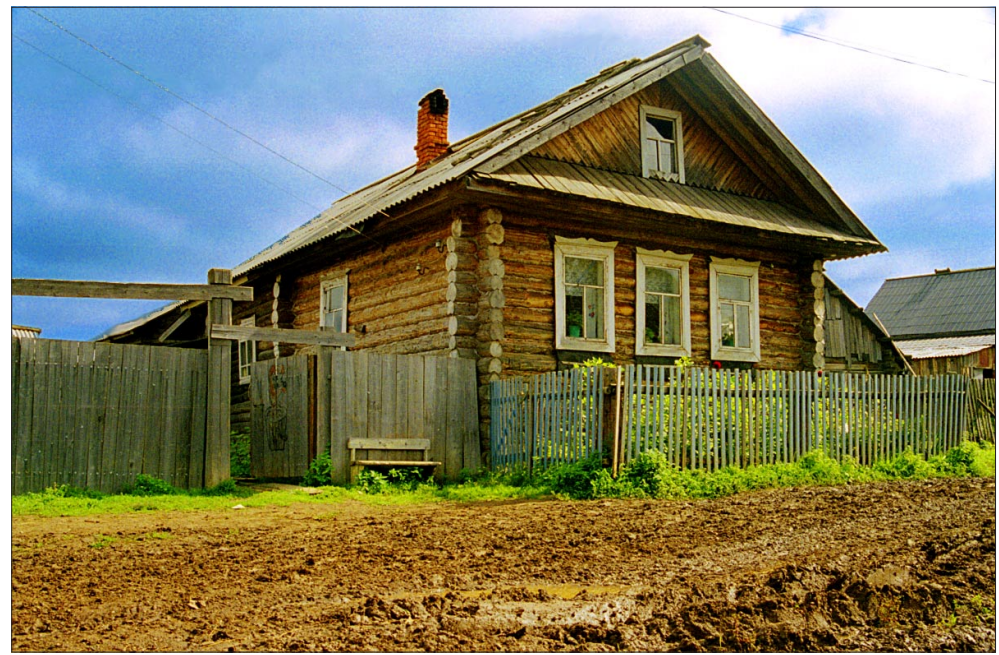

Photo 1. The Besserman village in Udmurtia. Photo by Andres Kuperjanov 2000.

ing crops, MI K72 Deceptive contest in carrying a horse; AT 1082 Carrying horse; MI K18. Thorwing contest won by deception; AT 1063 Slinging contest).

From the viewpoint of this article the most intriguing belief was that during yuletide vumurt came out of the water and dwelled in saunas.

\section{2. vožo (the meaning and etymology of the word will be discussed further below)}

Vožo dwells in water, rivers and ponds (MI G303.8.8. Devil lives in the water), but also in mills, saunas and empty houses. In some texts vožo is mentioned as a helper of a witch, who lives in a river or a spring (Bogayevski 1890: 90-91). In this case it is sometimes seen flying through the air (MI F451.3.3.6. Dwarfs fly through air; MI G242. Witch flies through air). Bogayevski notes that vožo is a fire snake who flies over the sky and brings family luck (Bogayevski 1890: 98 - treasure-bringer, cf to the Estonian treasure-bringing goblins puuk, kratt, and the Finnish para). The general belief was 
that vožo looked like a small hairy devil with tail, horns and hoofs (MI F420.1.4.6. Water-spirits with horse feet; F451.2.1.1. Dwarfs are small; G303.4.1.6. Devil has horns; G303.4.5.3. Devil has horse's foot; G303.4.6. The devil's tail).

Vožos often appear in great numbers. They come out of the water at night and dance and sing in abandoned houses and water mills (dancing fairies, witches, devils). They fear cock's crow (MI F383.4. Fairy must leave at cock-crow; F420.3.4.2. Water-spirits must be in water before dawn; G303.16.19.4. Devil (Satan) flees when cock is made to crow). They may drag a human not wearing a cross into the water (MI F451.5.9.1. Dwarfs fear the cross; G303.16.3 Devil's power avoided by the cross). During yuletide they came to the villages, dwelled in saunas and played evil tricks at humans (MI F451.5.2.7. Dwarfs play pranks; F451.5.2.10. Dwarfs frighten mortals).

\section{3. munčokuźo (sauna + master), munčo murt (sauna + man) tö d'i murt (white + man)}

A sauna fairy naturally dwells in sauna. It usually appears as an old man clad in white (MI F236.1.3. Fairies in white clothes; F451.2.7.4. Dwarfs clad in white). In some regions it was believed to have long hair and one eye. Southern Udmurts imagined munčokuźo as a small hairy creature. Trans-Kama Udmurts called the spirit inhabiting saunas kuźjirsi (the one with long hair; Sadikov 2000: 116). In some regions it was believed that saunas were inhabited by a multitude of spirits, who dance and sing at nights (ibid: 115). Sauna spirits / fairies also play tricks on humans, and may even exchange a child (MI F321.1. Changeling; F420.5.2.4. Water-spirits steal children and leave changeling; G303.9.9.4. Devil takes an unbaptised child out of the cradle and lays a wooden log in its place).

We may distinguish between three main types of motifs associated with water spirits:

(i) Motifs associated with water spirit, fairy and dwarf lore;

(ii) Motifs associated with the Devil and ignorant Old Heathen;

(iii) Motifs related to motifs about helpers/henchmen of the Devil (witches, vampires, treasure-bringers). 


\section{THE SEMANTIC MEANING AND ASSOCIATIONS OF THE WORD VOŽO}

The semantic field of the Old Permian word veža enabled its use as an equivalent for the Christian concept 'holy': йен вэжа лов - holy spirit, вэжа куима- Holy Trinity, вежа лун - holy day (Sunday) (Lytkin 1952: 156). In Modern Komi language vež also stands for 'holy/sacred' but also for 'cross': veža va - holy water, vežai - godfather (holy/cross father), vežań - godmother. Vežadir is yuletide (Russian святки), but the Komi-Zyryan veža also means 'filthy/impure' and 'the Devil' (Gribova 1975: 110). The verb vežni stands for 'exchange', vežöm was the child exchanged by the Devil or evil spirit in the Komi mythology. In the Udmurt language vožo does not directly mean 'holy' - this particular meaning becomes evident in connection with yuletide, called vožodir among the Udmurts, as well as the Komi. The Udmurts have a different name for its summer counterpart - invožo dịr - (sky + vožo + time/tide). The vožos are the previously-described demonic spirits. The word $v o z ̌$, closely related to vožo, means 'green, verdure, unripe' in the Udmurt language. In the expression 'vožde en vai' (don't be angry /don't bear a grudge!) it means 'anger'. The words vožominin (vožo + to go) 'get excited /heated' and vožpoton (vož + will/wish/feeling) 'anger' appear to derive from the same root. Interestingly, the Finnish words viha, vihainen 'anger, angry' and vihannuus, vihannoida 'green, to turn green' seem to share a common root.

Michael Agricola and Jacobus Finno have used the words wihleinen, wihileijnen, wihileitzet, wiheliaidzexi in the sense 'bad, vile, weak, impure/filthy, deceitful/dishonourable, faulty/spiteful' (SKES VI 1735).

Such words from the Estonian mythology like maaviha, küüneviha, perhaps also humalaviha may derive from the negative force emanating from these objects (earth, nail, hops). On the one hand the semantic field of the word vožo seems to approach the concept 'holy/ sacred' and on the other hand it can be associated with notions 'anger', 'green', 'evil' and 'impure'.

It is likely that such extended form of the semantic field may have originated in two different roots. The first could be associated with liminality, or existing somewhere in-between: *vaješ > Early Permian 


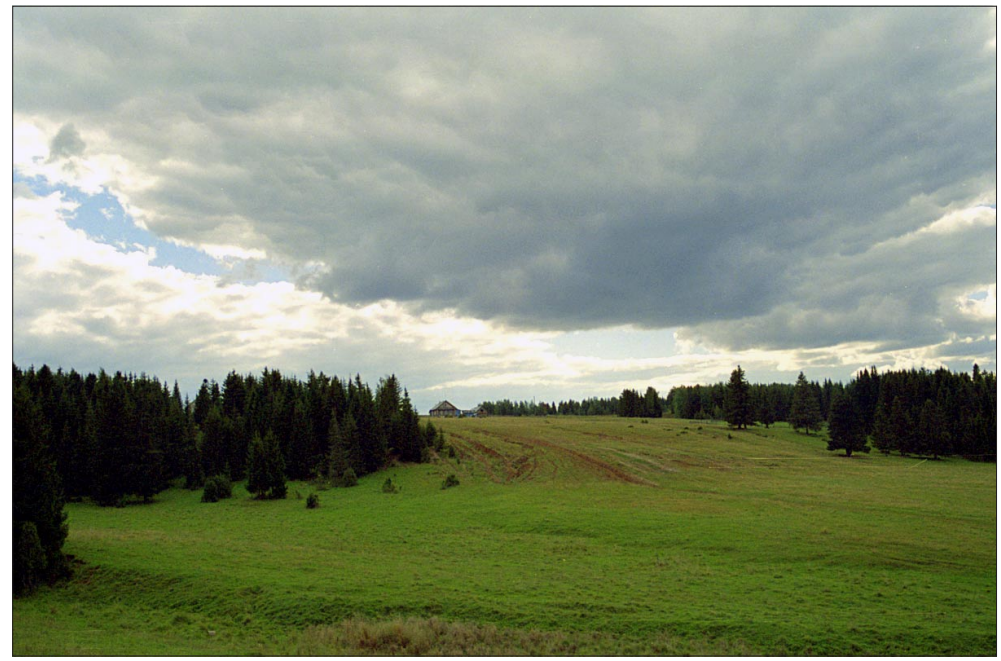

Photo 2. Northern Udmurtian landscape. Photo by Andres Kuperjanov 2000.

$v e \check{z}$ - > Udm. vož 'crossroad, river mouth, either of two warps, the crossing of warps and woofs, cf. vožen-vožen 'alternately, vožmin 'in turns', perhaps also invož (sky + vož) 'horizon'; Komi vež, viž - tuivež 'crossroad', vežn $i$ 'change'; Finnish vaihe, Estonian vahe 'difference, interval, gap' (SKES V: 1592-1593).

Finnish linguists have speculated on the relation of the Finnish vaihe and the Permian vež-, but had they been acquainted with the Udmurt or Komi mythology, this would not have been a mere speculation. In the Komi compound vežadir and its Udmurt equivalent the first component signified liminality, the solstitial period, or the extraordinary transitional period between two ordinary periods.

The second root was associated with the green colour, the bitter taste and strong emotions (like anger and lust): *viša > East-Mordvin

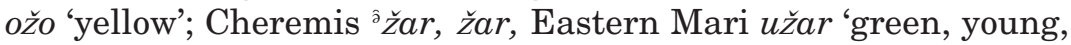
unripe'; Udm. vož 'green, unripe, small, anger, fury'; Komi vež 'green, yellow, envy, lust'. Cf. Finnish viha, vihainen, vihannuus, Old Hindi vișám 'poison', Avestan viša - viš zairitom 'greenish poisonous liquid', Pahlavi wiš ‘poison, bile, spiteful' etc. (SKES VI: 1734). In time 
the two roots approached towards each other and their meanings may have overlapped. An attempt to interpret the word vožodir as 'becoming angry or furious' occurs in earlier studies on the Udmurt mythology.

\section{LIMINALITY OF CROSSROADS AND RIVER MOUTH}

Crossroad or river mouth is certainly a liminal place, a place between two water bodies or roads. In his short monograph The Crossroad in Folklore and Myth Martin Puhvel has studied beliefs associated with crossroads in many traditions throughout history (Puhvel 1989). Interestingly enough, he does not mention liminality as the main characteristic of crossroads, although he presents numerous examples on how it was believed that the homeless/restless/placeless spirits gather in these particular places. In the mythologies of several Siberian peoples, a specific water body (river, lake) was associated with a specific supernatural creature, which functioned as a master/fairy of the body of water. Among the ObUgrians these spiritual beings were related according to a complex system, such as in the narrative about the Old Man of the Ob and the Fairy of the Salym River, recorded by Anzori Barkalaja:

As-iki is the master of fish. He makes fish and sends them into the nets of the fishermen. He also decides how many fish must go into each river. Once it so happened that the god of Salym (a tributary of $\mathrm{Ob}$. The god of Salym is the master of Thunder and notorious for his bellicose disposition - A. Barkalaya) thought he was getting too few fish from As-iki. So up he goes to As-iki and demands: 'Listen, why do you give me so few fish, give me more.' But As-iki was in a defiant mood, did not give him fish. So the god of Salym went away and began to prepare for war. He picked up an arrow-shaft and began to whittle away on it. Whittled one chip off it - the chip turned into a stickle-back. Whittled another chip - that, too, turned into a stickle-back. Thus the stickle-backs became many. They swam downstream into the river Ob. As-iki looks - a stickle-back. Looks again - nu, holera, (emotional interjection in Russian, translates as "Oh, cholera!") another stickleback! So he went upstream along the Ob until he could see - the Old Man of Salym is whittling away at arrow-shafts, chips are 
falling down and turning into stickle-backs. As-iki got a terrible fright, began to call from afar: 'What are you doing there, planning to wage war? Against whom?' Salym-iki called back: 'Against you, of course, why don't you give me fish?!' So As-iki reckoned the matter was grave and sent lots of fish into the Salym, many large pikes. Hmh (Barkalaja 1999: 69 > Semyon Pesikov, Lyamin, 1993).

The estuaries of rivers can then be regarded as territories between the domains of two similar supernatural creatures. Analogous beliefs are known about crossroads. Puhvel's examples on the inability of supernatural creatures to cross crossroads (Puhvel 1989: 97-98) seem to indicate as much. The liminality of crossroads is emphasised also by the association of various initiation rites and solstitial traditions connected with crossroads. The Awemba tribe in northern Zambia, for example, conducted ritual purification of young girls at puberty at crossroad (ibid: 73), in some parts of Europe (e.g. in France, northern Sweden) the midsummer fires were lit at crossroads (ibid: 75). Among many peoples, including the Estonians and the Udmurts, it was customary to perform various magical actions, especially foretelling, at crossroads.

\section{HOLY PERIODS}

Human lives and calendar years contain interim periods, characterised by indefiniteness due to the lack of boundaries. These periods are exposed to good and evil and are close to praeternatural.

The boundaries are a part of our system of orientation. With no limits the space would be homogeneous: there would be no difference between familiar and unfamiliar, good and bad, sacred and profane places. The same applies to time. Expressions like good times, bad times, difficult times, mad times, fast times, holidays, common days, childhood, youth, manhood, etc. clearly express evaluations and defining limits.

Transitions from one period, one stage of life, or one condition to another are like crossroads or partings of ways in time. When liminality renders the ordinary orientation dysfunctional, then ordinary behaviour will become ineffective or inappropriate. Differ- 
ent times need different behaviour. This is why people have carried out various practices, related to liminal conditions and periods and analytically called the rites of passage, throughout times.

\section{HOLY TIME IN THE UDMURT POPULAR CALENDAR}

Several restrictions were established for the summer and winter vožo-period:

The Votyaks of the Glazov county still hold a belief that during vožo-time it is forbidden to make noise, especially near a body of water: this is why people do not swim, or play singing games, or do the laundry in or near bodies of water in summer. In winter people do not do laundry in the river and avoid singing while crossing a bridge. During this winter period it is also forbidden to put out embers, like those falling from burning chips, by stomping... In the Gya, Lyp and Polom parishes the period of vožo was associated with the blooming of rye. ${ }^{6}$ Soiling water during this period was considered a grave sin-therefore it was forbidden to swim, wash the laundry or the dishes (even near a well), and even drive the herd into the river. The restrictions had to be followed especially around noon, when people tried to make no loud noises (Pervukhin 1888, 1:59-60).

U. Harva notes that violating the restriction caused suffering for the whole community, either in the form of storm or hail storm (Harva 1914: 174). Women in the village of Kuzebayevo have told the author that during the summer invožo-period it was forbidden to work with wool or hemp, it was also forbidden to mow and pick flowers. In Kuxebaevo this period ended at St. Peter's Day (July $\left.12^{\text {th }}\right)$. The invožo-period was often associated with the blooming of catchfly or Maiden Pink (invožo śaśka). In June 2003 some people of Varklet-Bodya village told: "vöś, pe, voź, vile pote invožo dirja" there is saying that during invožo period religion/belief/faith walks on the meadows.

The winter vožo-time was the main story-telling and riddle time for the Udmurts (Shklyayev 1989: 36). Even as late as in June 2002 three informants, living in the Udmurtskiy-Karaul and Deby villages in the Krasnogorskoye region, claimed that the words for 'rid- 
dle' in local dialect are vožo kill (vožo language/word/story) or vožo mad (vožo speech/word/story). ${ }^{7}$ Even though Pervukhin assumed that the word vožo mad may be interpreted as "the story of the winter vožo period" (Pervukhin 1888, 3: 70), and T. Vladykina seems to agree (Vladykina 1988: 11), this interpretation does not seem justified. On the one hand the word vožo mad referred to the traditional, ancestral nature of the text (cf. vižzi kill: myth: root/gender/ tribe/generation + language /word/story), on the other hand the word may have indicated the existence of a special style for communicating with visitors at solstices, the artistic style of folk tales and riddles.

In Russian folklore water fairy sleeps in winters and is at the peak of its action in midsummer, from the Midsummer Day ${ }^{8}$ to St. Peter's Day or to St. Eliyah's Day [in the beginning of August] (Krinichnaya 1994: 19-21), i.e. during the period that the Udmurts call invožo dir. In Russian accounts the most dangerous time for bathing and swimming was noon and midnight, but also early in the morning and late at night (ibid.: 21-22). The Votian water spirit is also active in summer (especially around the Midsummer Day); a ram was reportedly sacrificed to it at the River Lauga on St. Eliyah's Day, while saying: Nahh, süü boranaa päit, elä süü inemisii! (There, eat the ram heads, not people!) (Västrik 1999: 24, 25). We may only speculate on whether the sacrifice was supposed to symbolise the end of the water spirit's period of activity.

\section{VISITORS OF THE LIMINAL PERIOD}

The Udmurts of the Glazov County believed that water spirits came into the villages and inhabited the saunas before Christmas. In the twilight they could be encountered on the street:

During the summer vožo dir it sleeps, but on winter solstice (before Christmas) it leaves the water and spends most of its time in saunas, though it could be met on the street. This is why no Votyak dares to walk alone on the streets without a burnt chip during Christmas (Pervukhin 1888, 1: 75).

The water spirits of the Christmas period were mostly called the vožos. Pervukhin continues: 
From December $25^{\text {th }}$ to January $6^{\text {th }}$ small (no longer than a few archines tall), colourful, though relatively similar-looking devils (with tails and horns) walk on the streets of villages, settlements, even the town of Glazov. The Russians call them kulish, the Votyaks vožo. Like water spirits, the vožo fear even the smallest piece of burnt chip. [---] Those, who walk around without a chip, will be tripped up by the vožo. [---] for the same purpose they turn into a post, or a corner of a house... They may take a man to his neighbour's house instead of his own, and may make a woman drive other people's cattle to her own yard... (Pervukhin 1888, 1: 99-100).

For the Udmurts, vožodir is the period for mumming. The most common name for mumming is pörtmaśkon, cf. pörtmani - 'to change, to transform, to slander'. Other words for mumming are pendzaśkon (cf. pen 'soot, ashes', pendzini incinerate, to burn to ashes', referring to the most common way of masking by smearing the face with soot or ashes), vožojaśkon vožoaśkon ("vožoing"; in several regions the mummers called themselves the vožo) and čokmorskon. The latter derives from the word čokmor - wooden club (cf. Russian чекмарь 'wooden club, beater' < чека 'wedge, pole') and refers to the banging of house corners and floors with sticks and clubs, a characteristic activity of the mummers, which helped to repel evil spirits and diseases from the house and the village (Vladykin 1994: 227). The Udmurt Christmas mummers almost seem to have split personalities: the fact that they wore clothes inside out, had faces smeared with soot, men were wearing women's clothes and women were wearing men's clothes, indicate that they were visitors from the otherworld (where, according to the universal belief, things are reverse to this world). The fact that they were believed to bring luck in herding relates them to the souls of ancestors, who were universally considered the primary bringers of herding luck in many cultures. And, last but not least, the mummers were addressed to as the vožo, which were undoubtedly related to the dead ancestors.

The Udmurt Christmas mummers also functioned as repellers of evil forces. Vladykin mentions an account, describing how mummers ran along village streets, screaming loudly, banging against the corners of houses, and on the floors inside the houses, frighten- 
ing the sauna spirits (munčokuźoos Vladykin 1994: 226-227), though according to a fairly commonly held belief the vožos inhabited the saunas. As I have indicated before, no clear distinction was made between the sauna fairies and the vožos. The exorcistic function of the Udmurt Christmas mummers very likely originates in the traditions associated with the end of the solsticial period.

The winter vožo-period ends on January $19^{9}$ (or the Epiphany of Jesus according to the Orthodox calendar) with a feast day called vožo kel'an 'the sending off, or the departure of vožo' or jö vilin silon 'standing on ice'. On the night before January 19 the youth of the village walked from sauna to sauna, singing songs and "listened to their fate" and told the vožo: pot tatiss milemesti-leś! ('Leave us!'). The next morning all the men went to the river and banged on the ice with their axes and clubs, shouting : koški tattiss'! ('Leave this place!') (Pervukhin 1888, 2: 105-106).

\section{THE FORMATION OF THE CONCEPT 'HOLY' AMONG THE PERMIAN PEOPLES}

Considering that the word vožodir denoted the liminal period of the winter and summer solstices and was not a recent loan from the Russian святки, and considering that the vоžоos were the praeternatural visitors of this period, probably related to departed ancestors, we may now observe the formation of the concept 'holy' among the Permians.

The solstice was a special and dangerous period, and the supernatural visitors of this period were expected but were considered dangerous and required special treatment. The concept 'holy' was closely related to the strange, the special, the liminal, the dangerous and the desirable. Before the introduction of Christian terminology, the Permian word for such phenomena was vež. Words derived from this root were likely used to signify places, periods, objects and creatures that required special treatment, including transitional or interim periods in calendar and geographical and territorial border areas. As the concept also comprised the sacred places for worship and cult objects, the word vež seemed most appropriate for the Permian equivalent for the Christian concept 'holy', and Stephan of Perm soon adopted the word in Komi. Even though the 
Second Commandment declares that for I the Lord thy God am a jealous God (Ex 20: 5) and the Second Book of Moses writes that "for the LORD, whose name is Jealous" (Ex 34: 14), the Christian concept of "holy wrath" is less inclined to the unknown, liminal and dangerous. The supernatural visitors of the solstitial period were no longer included in the semantic field of the concept (ve ̌̌), and became to be called the Chudes.

Common conceptions about the Chudes may be divided in three major groups: (i) the Chudes were a people living on the upper course of the River Kama and the Vychegda River long before the Komi; (ii) the Chudes were the Komi before their conversion into Christianity; (iii) the Chudes were the Komi heros (Gribova 1975: 93). The Chudes objected to the arrival of tall people. They hid themselves in saunas and holes, and threw stones and coals at the newcomers. The holes of the Chudes are still there: they probably fell down through them (ibid: 95). They were the Komi, only unbaptised like the Chudes. When they were Christianised, they believed it was something bad and hurt themselves: they built dugouts, descended to these dugouts and severed through the beams supporting the ceilings...(ibid.: 96).

The Komi also attributed the name Chudes to vožo-like creatures:

According to the Komi-Permyak beliefs the Chudes are ...small anthropomorphic black creatures, who live in dark places: in abandoned houses, saunas, drying barns, cellars, inside the house behind the oven and under the floor, in the woods and in water. They are, in fact, called the sauna-Chudes, barn-Chudes, etc. They cause troubles for humans: frighten (especially at Christmas), drag to eddies, smother in the sauna. Sometimes they steal children and place a wooden log instead. These children are called "woodlogs" or vežöm 'exchanged'. The exchange is particularly successful when the child is unbaptised or does not wear a cross around its neck. The exchanged child may eat and drink as much as it likes, but it will neither grow nor develop (Gribova 1975: 107).

Regardless of the several presented etymologies tracing the origin of the word Chude to more distant languages, I tend to support the Slavic origin of the word ( чудо, чудый, ethnonym чудь, which the 
Christianised Slavic tribes appeared to have used for heathen FinnoUgrians). Similarly to the visitors of the liminal period, who were associated with deceased ancestors, the Christian Komi attributed the Chudes a new identity as the heathen forefathers or heros and demonicised them. Several folklore texts of the Komi describe the demonisation of the heathen ancestors of the Christianised Komi:

The Kars, ${ }^{10}$ these were the towns: Kudym Kar, Kureg Kar. People lived underground, built loghouses and lived on meat and fish. [---] But later, when the conversion into Christianity began, they began to destroy themselves, buried themselves alive. Who refused to be baptised, he was not allowed in the house. Walked around as a Chude - small, pitiful, was afraid of everyone. ${ }^{11}$ These were the years of spirits - you pass the sauna, pass the river - it haunts everywhere. Even when doing needlework. But they would not surrender, slept in the sauna, or in the threshing barn. Even now they are called "the sauna-Chudes" (Limerov 1998: 39).

Stephan of Perm's influence did not affect the Udmurt area, and the later coiners of Christian terminology in the Udmurt language were probably unable to see the relation between the Udmurt vož/ vožo and the Christian concept 'holy/sacred'. For this reason the Udmurts do not have their own word for this and use Russian loans святойаnd священной (e.g. a recently collected modern prayer: svjatoi ińmar, sujatoi kulontem, mil'emlị d'źečkar - Holy God, Holy Strong, Holy Immortal, have mercy on us [lit. do us good] ${ }^{12}$ ). At the same time there was no need for the new name of the visitors of the solstitial period, who continued to be known as the vožos, and were demonicised. The demonisation of analogous mythological characters, like various fairies, spirits and dwarfs, in the mythologies of different countries is suggested by the motifs presented in the beginning of the article.

In the Permian language the Christian concept of 'holy/sacred' was derived either from the word originally denoting the liminal, the unusual, perhaps even the impure (the Komi example), or was a loan word (the Udmurt example). The study of toponyms should reveal whether veža and vožo were used in religious sense. A good example from the Komi language is perhaps the Khanty-Mansi sacred place at the River Ob, Jem voš / Jalp uus, the residence of the mythological Old Man of the Holy Town, which after the Komi ex- 
pansion became to be called by its literal equivalent Vežakary, or the Holy Town. Toponyms, however, will not be very useful, because in the Udmurt language it is difficult to distinguish between the notions vož ('green, anger') and vožo (the original meaning 'holy'). We may speculate that the village name Vožešur and the river name Vožoi šur may originate in the concept 'holy' rather than the 'green', therefore meaning 'the Holy River', and also the village name Vožoika, but we cannot be absolutely certain, especially because it is clear that the village name Vožkyr originates in the notion 'green' and has the meaning of 'green woodpecker'.

The Permian example enables to explicate Veikko Anttonen's argument that the concept of 'holy' is associated with impureness - his assumption was strongly misunderstood by Anzori Barkalaja in his master's thesis (Barkalaja 1996: 23). Having accused several other authors for being too "progressive", Barkalaja seems to have fallen into his own pit, as he refused to admit the possibility of the change of religious concepts in time. Like the concept of 'holy', the concept of 'filthy/impure' has definitely changed as well. In several traditional cultures the objects associated with birth and death often require special treatment - the objects are taken into certain wood groves or other places, sanctuaries, distinct from ordinary places. A woman who is considered impure during menstruation and in the postnatal period requires special treatment: she is often isolated, either symbolically or physically, from the rest of the community. In the Mansi villages there are specific houses man kol (the small house) for this purpose, where other villagers would not go. Harriet Lutzky has argued that the Latin sacer derives from the Indo-European roots *sak- or *sek-, which both mean 'to cut, to set apart', therefore sacralised through separation (Lutzky 1993: 285-287). Emile Benveniste has argued that the Latin adjective sacer had two contradictory meanings: (a) he who belongs to gods and (b) he who is cast out, afraid, damned. The person, who was marked with the word sacer, was considered impure and therefore a social outcast. The one given to gods (sacer) as well as the impure (sacer) signified whoever or whatever was cast/"cut" out of human society (Benveniste 1973: 453). This cut-off or separated object served as the bridge, doorway, threshold or path (whichever metaphor you choose) connecting the everyday world and the supernatural sphere. Even Je- 
sus, the Son of Mary was cast out of human society in birth and in death. Especially for that reason he was authorized to say, I am the way, the truth, and the life: no man cometh unto the Father, but by me (Jh 14: 6). According to Veikko Anttonen the two main features of the 'holy' category are anomality and liminality (Anttonen 1992: 2526). The formation of the concept 'holy' among the Permian peoples illustrates and supports this Anttonen's statement. Liminality was undoubtedly an important distinguishing feature between the holy and the profane. Another example of such threshold between the two spheres are the inscriptions above church doors or gates Hic est domus Dei et porta caeli.

\section{CONCLUSION}

I hope the article helped to clarify why supernatural visitors related to deceased ancestors come from water and how and why are they related to water spirits in the Udmurt mythology. The answer is quite simple - according to a commonly held belief the realm of the dead is situated on the other side of water (often on an island in northern sea), or it was believed that the pathway to the otherworld runs downstream along the river. It is quite logical to believe that if the dead (or their souls) descend to the realm of the dead downstream the river, they will return to visit their living relatives upstream.

I am aware that the Udmurt vožos and the Komi vežas or Chudes have counterparts in other North-Eurasian mythologies. For example, the Russian кулиш куляш and шуликун. The etymologies of these words are quite intriguing. Кулиш and куляш originate in the Ugrian and/or Permian languages (cf. the Mansi kul'or kul'otor 'Lord of the underworld, the Devil', Komi kul'water spirit, the Devil'; шуликун оr шиликун appear to be linguistically, as well as mythologically related to the character sülü̈̈kün süllükün in the Yakut mythology (speculated origin in the Old Turkic word suvlu $\gamma^{6}$ water-, water-related'). Parallels could be drawn also with the demonic Christmas visitors of the Russians, Yakuts and Udmurts. Here I am not saying that the Russians have borrowed their solstitial visitors from the Turkic or Finno-Ugric peoples. It is highly likely that 
the Russians had their own word for such supernatural creatures, and the name was either abandoned or was attributed a new meaning. As to the names of St. Martinmas' and St. Catherine's Day's mummers (mardisandid, kadrisandid) in the Estonian tradition, the word sant ('beggar' or 'cripple' in Modern Estonian) seems to be either a similar loan for the same purposes, or was borrowed from the official language used at contemporary liturgy with a purpose to rehabilitate the spiritual visitors in the eyes of Church.

\section{Comments}

${ }^{1}$ Especially by N. Pervukhin, but also by I. Vassilev, P. Bogayevski.

${ }^{2}$ Literally - 'standing on ice'. On the previous night the village youth performed a ritual called vožo kelan - 'sending off or the departure of vožo', walking from sauna to sauna, shouting loudly, in order to repel the vožo, who had went to live there during Christmas.

${ }^{3}$ The plural form of vožo, i.e. the vožos.

${ }^{4}$ In the Komi mythology Kul' is both the Devil and an evil water spirit. Kulpijannez could be the diminutive form - sons/cubs of the Devil.

${ }^{5}$ On references to the origin of the Udmurt motifs see Lintrop 2000.

6 The motif of water sprites walking in the fields during the blooming of rye is also known in Russian folklore (Krinichnaya 1994: 23).

${ }^{7}$ The ethnic genre name for riddles, vožo mad', is mentioned in Gavrilov 1880: 54, Pervukhin 1888, 3: 70); Wichmann (1901: 6-7). Pervukhin has used the same word for folk tale. The more common modern term for riddle is madiskon kil or madkil.

${ }^{8}$ In the Yaroslavl Guberniya the Midsummer Day was considered the water spirit's name day (Krinichnaya 1994: 19).

${ }^{9}$ Januari 6 by old stile.

${ }^{10} \mathrm{Kar}$ - town, township in Permyak language.

${ }^{11}$ Originally: чудливые ведь годы были - мимо бани идешь, мимо реки, так всюду чудится.

12 The prayer derives from the Orthodox liturgy Trisagion Святый Боже, Святый Крепкий, Святый Бессмертный, помилуй нас (Holy God, holy 
Strong, holy Immortal, have mercy on us), which in the Udmurt language sounds as sujatoi ińmar, sujatoi kulontem, milemli d'źeč kar.

\section{Reference:}

AT = Aarne, A.; Thompson, S. 1961. The Types of the Folktale, FFC nr. 184. Helsinki.

Anttonen, V. 1992. "Püha” mõiste rahvausundi uurimises. Akadeemia, nr. 12, lk. 2514-2535.

Barkalaja, A. 1996. Handi rahvausundist, selle seostest vene õigeusu ja teadusliku mõtlemisega. Väitekiri magistrikraadi taotlemiseks eesti rahvaluule alal. Tartu Ülikool, eesti ja võrdleva rahvaluule õppetool.

Barkalaja, Anzori 1999. On the Sacrificial Rituals of the Pim River Khanties: Part Two. Pro Ethnologia 8, Arctic Studies 3. Tartu, pp. 57-71.

Benveniste, E. 1973. Indo-European Language and Society. London.

Bogayevski 1890 = Богаевский П. М. Очерки религиозных представлений удмуртов. Этнографическое обозрение но. $1,2,4$. Москва.

Gavrilov 1880 = Гаврилов Б. Произведения народной словесности, обряды и поверья вотяков Казанской и Вятской губерний. Казань.

Glukhova 2002 = Глухова Г. А. Символика ряженья в традиционной культуре удмуртов. Автореферат диссертации соискание ученой степени кандидата филологических наук. Удмуртский Институт истории, языка и литературы Уральского отделения Российской Академии Наук. Ижевск.

Gribova 1975 = Грибова Л. С. Пермский звериный стиль. Москва.

Harva 1914 = Holmberg, U. 1914. Permalaisten uskonto. Suomen suvun uskonnot IV. Porvoo.

Krinitchnaya $1994=$ Криничная Н. А. На синем камне. Мифологические рассказы и поверья о духе-«хозяине» воды. Петрозаводск.

Limerov 1998 = Лимеров П. Ф. Коми несказочная проза. Сыктывкар.

Lintrop = Lintrop, A. 2000. Udmurdi usundi peamised tunnusjooned XIXja $X X$ sajandil. Doktoriväitekiri. CD. Tartu.

Lutzky, H. 1993. On a Concept Underlying Indo-European Terms for the Sacred. The Journal of Indo-European Studies, 21, pp. 283-301.

Lytkin 1952 = Лыткин В. И. Древнепермский язык. Москва.

MI = Thompson, S. 1932-1936. Motif-Index of Folk-Literature. FF Communications No. 106-109, 116, 117. Helsinki

Pervukhin $1888=$ Первухин Н. Г. Эскизы преданий и быта инородцев Глазовского уезда. Эскиз 1., Эскиз 2., Эскиз 3., Вятка.

Pletneva 1999 = Плетнева И. Н. К семантике удмуртского вожо. Проблемы удмуртской и финно-угорской филологии: Межвузовский сборник научных трудов. Удмуртский университет, кафедра общего и финно-угорского языкознания. Ижевск.

Puhvel, M. 1989. The Crossroads in Folklore and Myth. American University Studies. Series IV, English Language and Literature, vol. 88, New York. 
Sadikov, R. 2000. Kaama-taguste udmurtide ettekujutused elamu kaitsevaimudest. Mäetagused, nr. 13, lk. 112-118.

SKES 1975, 1978. Suomen kielen etymologinen sanakirja. V, VI, Helsinki. Shklyayev 1989 = Шкляев Г. К. Обряды и поверья удмуртов, связанные с жилищем. Фольклор и этнография удмуртов: обряды, обычаи, поверья. Ижевск, с. 28-43.

Vereshtshagin $1996=$ Верещагин Г. Е. Вотяки Сарапульского уезда Вятской губернии. Собрание сочинений, т. 2. Ижевск.

Vladykin 1994 = Владыкин В. Е. Религиозно-мифологическая картина мира удмуртов. Ижевск.

Vladykina 1998 = Владыкина Т. Г. Удмуртский фольклор: Проблемы жанровой эволюции и систематики. Ижевск.

Västrik, E.-H. 1999. The Waters and Water Spirits in Votian Folk Belief. Folklore, vol. 12, pp. 16-37.

Wichmann, Y. 1901. Wotjakische Chrestomatie mit Glossar. Helsingfors. 